Visit us - www.researchjournal.co.in D DOI : 10.15740/HAS/IRJAES/10.1/166-170

International Research Journal of Agricultural Economics and Statistics

Volume 10 | Issue 1 | March, 2019 | 166-170 ISSN-2229-7278

\title{
A Case Study Sales of fertilizer in Kharif, Rabi and summer season in Shrirampur and Nagar tahasil
}

\section{P. A. Shelke and A. S. Kshirsagar}

ABSTRACT : This study was conducted between June 2018 to Aug. 2018 on sample of 12 wholesaler and 18 retailer. This research paper have examine the sales of chemical fertilizer in Shrirampur and Nagar taluka. Primary data were collected by survey method and visits to tahasil office in both talukas. After analyze the collected data shows approximate 60 per cent of fertilizers sales of Nagar and Shrirampur tahasil is in Kharif season. The sales of fertilizers is depends on the level of availability of irrigation. Water availability is high in Kharif cropping season (June to September). This results are based on wholesalers and retailers annual sales (monthly) of fertilizer. In this research paper tables and pie charts contains data of fertilizers sales in Nagar and Shrirampur talukas.

KEY WORDS : Marketing, Sales, Retailers, Wholesalers, Cropping seasons

How To Cite This Paper : Shelke, P.A. and Kshirsagar, A.S. (2019). Sales of fertilizer in Kharif, Rabi and summer season in Shrirampur and Nagar tahasil . Internat. Res. J. Agric. Eco. \& Stat., 10 (1) : 166-170, DOI : 10.15740/HAS/IRJAES/10.1/166-170. Copyright@ 2019: Hind Agri-Horticultural Society. 